\title{
From Making Things Public to the Design of Creative Democracy: Dewey's Democratic Vision and Participatory Design
}

\author{
Participatory design's (PD) shift from the workplace to civic settings has led to a \\ reorientation of the field's political bearings. Informed by science and technology \\ studies, practice is now often framed in terms of design Things, infrastructuring \\ and John Dewey's concept of 'publics'. Taking the publics concept as a starting \\ point, the present article seeks to contribute by providing a broader outline of \\ Dewey's democratic vision. It is proposed that Dewey's vision may be seen to \\ offer a potentially useful perspective that directly relates the 'publics' concept to \\ the areas of freedom, experientialism and the institutions of government. Linking \\ to contemporary developments in PD and beyond, the vision is seen to carry \\ conceptual and practical implications, which, if borne out, would connect the \\ discipline's capacity to 'spark' publics into being to the processes of policy \\ formation and institutional reform.
}

Keywords: Participatory Design, Democracy, John Dewey, Institutioning, Design for Policy, Science and Technology Studies

\section{Introduction}

The last two decades have seen participatory design (PD) shift its contextual focus from the workplace to smaller civic settings. This shift has led to a degree of anxiety over the movement's political bearings, with some arguing that these more limited engagements have led to a narrowing of PD's original, broad-ranging agenda (e.g., Huybrechts, Benesch and Geib 2017). While there have been a number of recent proposals calling for a refocusing of the political in PD (e.g., Teli, Fiore and D’Andrea 2017; Binder et al. 2015; Björgvinsson, Ehn and Hillgren 2010), the present article explores the discipline's relationship - actual and possible - to formal democracy.

This exploration is given form and structure through a careful referencing of the 
democratic writings of the pragmatist philosopher John Dewey (1859-1952). Dewey's philosophy has long resonated with the PD community (see e.g., Ehn 2017; Telier 2011, 9-10). and by returning focus to Dewey's democratic writings, I am here aiming to draw out a set of conceptual and practical implications, which to point to the potential of a wider political reach for the field. Although no case studies are presented, towards the latter end of the article I link to the contexts and perspectives of frontline practitionerresearchers working in the UK and mainland Europe.

\section{Democracy in PD Today}

PD has long been concerned with democracy. The Scandinavian workplace projects of the 1970s and 1980s centred on equality and worker's rights, as well as the belief that those use a technology should have a say in its design (e.g., Bjerknes, Ehn and Kyng 1987). However, as the project contexts have changed so too have its political parameters. Indeed, recent years have seen the advance of an increasingly complex discourse, integrating concerns relating to power, agency and the existential trajectories of issues. Here, many have been inspired by the theories of science and technology studies (STS), which productively enmesh humans and non-humans, material practices, processes and events (see e.g., Sismondo 2003; Latour 2005a).

In referencing this work, the PD community has, for the most part, tended to focus on the contributions of Bruno Latour, Susan Star and Noortje Marres. Following Latour's lead, several theorists evoke the Heideggerian notion of 'thinging' as a means of conceiving of the extended interweaving of social and material relationships brought about by design (Telier 2011). 'Design Things', assemblies, are said to come into being as these socio-material relations inform and shape ways of interacting and behaving, allowing for exploration, discussion and debate (see Telier 2011; Björgvinsson et al. 
2010; 2012). Linking to this, Star's concept of 'infrastructuring' is also drawn upon to convey the complicated "performative "staging" of design Things over an extended period of time, including bringing about the conditions which allow for full democratic participation (see Björgvinsson et al. 2012, 103-105).

In addition to the above, another Latourian contribution emerges through his call to 'make things public'; that is, to find ways of mobilising socio-material things as matters of concern (see Latour 2005b). This is complimented by the work of Marres who has formulated a theory of 'material publics', which acknowledges the role that things, animate and inanimate, play within the political process (e.g., Marres 2012). In both cases, the term 'public' is a reference to the work of the John Dewey - in particular, his 1927 text The Public and its Problems. Through Marres and Latour, both the notion of 'making things public' and the Deweyan publics concept have become established points of reference within PD (e.g. Björgvinsson et al. 2010; DiSalvo 2009; Binder et al. 2015; LeDantec 2016).

\section{Dewey's Publics Concept and its STS Interpretation}

John Dewey was one of the twentieth-century's most prolific champions of democracy (e.g., Westbrook 1991). The Public and its Problems can be seen as a plea to revitalise democracy at a time when the concept was both unfashionable and under extreme threat (Narayan 2016, 15). As the title suggests, publics, that is, an active, politically-engaged citizenry, are seen as central to this process of revitalisation.

In defining his conception of a public, Dewey works outwards from the position that the communal activities of collectively planning and pursuing desired goals together will necessarily result in consequences; the impact of which may be limited to the initiating group or, alternatively, may extend further to involve other actors. From this, he goes on to propose that, given sufficient motivation (whether positive or 
negative), the latter actors may come to form 'a group distinct enough to require recognition and a name.' Such groups are referred as a public. Once organised, he takes the view that a public will likely require that its interests be overseen by a set of representatives, who, in turn, will be charged with the general regulation of community life. This system of representation, he suggests finally, may be seen to form the basis of government and, ultimately, the political state (LW 2, 257). ${ }^{1}$

Later on in The Public, Dewey goes on to develop this quasi-historical overview, giving the concept a modern framing. In this context, as will be detailed below, he is concerned with connecting communities, publics, to the institutions of government.

To a large degree, the popularity of the publics concept in PD can be attributed to Making Things Public, an exhibition and, later a publication by Latour and Peter Weibel, examining how various socio-material formations might 'spark' publics into being (see Latour 2005b). In this work, Latour explicitly acknowledges his debt to Noortje Marres's framing of the Deweyan publics concept (ibid, 14) and Marres, in turn, is widely referenced on the subject in PD literature (e.g., Le Dantec and DiSalvo 2013; Binder et al. 2015).

Marres draws on Dewey's articulation of the public as a means of developing STS's 'issue-orientated' perspective on public involvement in politics. She argues that the publics concept may be seen to supply STS with a necessary rationale for why a politics of public issues, whether concerning roads or epidemics, must by necessity take the form of democratic politics (2007). This opens up a view of public involvement -

\footnotetext{
${ }^{1}$ Following the convention of Dewey scholarship, in referencing his Collected Works I am using the initials LW in combination with a number to denote particular the particular Later Works volume in which the reference appears.
} 
publics - as 'being occasioned by, and providing a way to settle, controversies that existing institutions are unable to solve' (759); public issues, in turn, are seen as resistant to 'institutional settlement' (772). This understanding is mirrored by Latour who (drawing on Marres) takes the view that the emergence of a pragmatist public denotes that 'something went wrong', that an issue has emerged which extends beyond the 'normal routines of action' and, as such, requires participation (2007, 818-819).

A crucial point here is that neither Marres nor Latour (via Marres) represent the positive link Dewey draws between publics and representation, publics and government. In moving to ground the Deweyan public in an STS context, Marres draws attention to what she sees as the necessarily antagonistic nature of public affairs. Issues, we are told, are always partially irreconcilable. Different groups bring different perspectives; each public 'distils' a different aspect of a controversy (Marres 2007, 773).

On this presentation, public involvement is necessarily complex and tense, its forms infinite and its outcomes by no means clear. Most importantly, in losing its positive link to representation/government, it lacks a clear outward orientation, its issues have nowhere in particular to go. In the words of Latour, each new issue 'deserves its own protocol' $(2007,819)$.

\section{Dewey's Publics Concept in PD}

In recent PD literature, the publics concept has most clearly come to the fore in the work of three key theorists - Pelle Ehn, Christopher Le Dantec and Carl DiSalvo.

Ehn regularly references the Deweyan public in his discussions of the 'agonistic public spaces' of Malmö’s Living Labs (e.g., Björgvinsson et al. 2010; 2012). Such spaces aim to bring diverse groups together to explore 'questions and possibilities' in open-ended, small-scale experiments (Björgvinsson et al. 2010). On this account, 
Dewey's public points to the 'heterogeneity and conflict' that emerges as Things become matters of concern (Björgvinsson et al. 2012, 116). More recently, Ehn and others have gone on to draw a more explicit alignment between this approach and actor network theory (Binder et al. 2015). They call for a 'reinvigoration of participatory design as laboratory of democratic design experiments' (160).

Following on from Ehn, Le Dantec and DiSalvo can be seen to approach the concept similarly. Le Dantec has explored the extent to which publics may be constituted through the development and use of technology (e.g., Le Dantec 2016; Le Dantec 2012; Le Dantec and DiSalvo 2013). On his theorisation, publics are constructed around issues, attachments and infrastructure. All three aspects may be transformed as design shifts the parameters of the situation (Le Dantec 2016, 7). He argues that 'constituting and supporting a public' requires more than 'passing encounters with a mediating technology'. A public must also have a role in 'determining the future use of that technology and the development of legitimate claims to shaping that future' (Le Dantec 2012, 1359). Next to this, DiSalvo references Dewey's concept of public in his presentations of community-based PD projects (e.g., DiSalvo 2009). His core argument is that by developing and applying specific tactics - for example, the 'projection' of future scenarios - design can meaningfully contribute to the construction of politicallymotivated communities (DiSalvo 2009).

Drawing their reference from Marres and Latour, this research foregrounds design's role in 'sparking' publics into being around local community issues and controversies. It is my contention (elaborated below) that in following the indeterminate Marres-Latour definition of publics in issue-formation, there is a tendency for these inquires to remain local. 
For example, Ehn and colleagues' work has largely been focused in the city of Malmö. In one case study, they introduce a hip hop community from a disadvantaged area of the city to a variety of specially-designed technological platforms. This is seen to allow for the formation of new relationships at the city-level - the community's music is distributed in novel ways, a mobile app encourages others citizens to visit and explore their neighbourhood (see e.g., Björgvinsson et al. 2012).

Le Dantec and DiSalvo openly acknowledge their smaller scale publics as they detail similar engagements with, for example, a community group working to address post-industrial decline (Le Dantec and DiSalvo 2013). In this case, the design team and participants collectively explored the possibility of developing a sensor-based community radio program to promote the local area (253). This shared goal was seen to strengthen group resolve, galvanising its membership and encouraging external collaboration.

It is beyond question that all of these publics and their issues are genuine, that the processes of issue formation produce distinct benefits and the 'design Things' they represent do form novel assemblies. Yet, at the same time, it can also not be ignored that these cases are contained at, what Liesbeth Huybrechts and colleagues term, the 'mirco-political scale' of PD (Huybrechts, et al. 2017, 150). In other words, the publics and the Things described do not, in the end, appear to extend far beyond their immediate context, i.e., few 'meso' or 'macro' political developments are in evidence; further, there is little sense that this might (in some cases) be desirable.

Of course, in highlighting the above - both the Marres-Latour and PD appropriations and translations of the publics concept - it is important to recall Marres's aim. She is seeking to provide 'argument resources' for political STS in the context of 
issue-formation. As such, she reconstructs Dewey's concept in relation to her own concerns.

This reconstructed presentation is clearly of value but we are missing its bearings; as was noted above, the issues have nowhere to go. PD, in referencing Marres (and the Latour of Making Things Public), has little sense of Dewey's publics in context. This context is his democratic vision and the democratic vision, in turn, articulates a Deweyan why and how for democracy. As we shall see, I believe that it is the absence of Dewey's how of democracy, in particular, that contributes to the containment of PD's real-world publics at the local and micro-political levels (Huybrechts et al. 2017), thus, cutting off the meso and macro and limiting the potential political reach of the discipline itself.

In seeking to counter this at the same time as map out a renewed political path for PD, I will now move to provide an overview of Dewey's democratic vision.

Of course, this undertaking presents a number of challenges. First, there is the broad sweep of Dewey's original writing. A full appreciation of the breath of the vision requires extensive cross-referencing, not to mention a sensitivity to the evolution of his arguments. Alongside this, there is the space that opens up beyond the Deweyan vision. This is, by necessity, speculative.

Responding to these challenges, a focused approach is taken through the following sections. In outlining Dewey's democratic vision I refer to three core concepts; namely, positive freedom, creative democracy, and social intelligence, which, together, ground its social, political and practical aspects. From this, I will move to look at the potential implications of this perspective for PD. Here, my focus will be directed towards the emergent area of design for policy and 'institutioning' (Huybrechts et al. 2017). In linking these against the background of Dewey's vision, I will argue that it 
becomes possible to frame an opportunity space for PD within the bounds of contemporary practice.

\section{Dewey's Wider Democratic Vision}

Perhaps the key to understanding Dewey's democratic vision lies in appreciating the distinction he draws between democracy as a political system and 'democracy as a way of life' (Pappas 2008, Narayan 2016). Though Dewey acknowledged the role of political institutions, he argued that, firstly, democracy must be seen to originate in conduct of everyday affairs and the advance of community interests (e.g., Dewey LW $14,224-230)$.

In pursuing this agenda, he gradually came to develop a set of core concerns focusing on: the relationship between the individual and society; the quality of communication and cooperation among groups; and the particular methods and techniques by which democracy could be enabled, sustained and enhanced. These concerns can, in turn, be seen to underpin the conceptual structure of Dewey's democracy vision. Here we encounter positive freedom, creative democracy and social intelligence.

\section{Positive Freedom}

For Dewey, each individual can be understood to form an 'association'. What a person does, what their experiences consist of, he argues, 'cannot even be described, much less be accounted for in isolation' (LW 2, 353). This life of association can be seen to both constrain and support the individual - the accompanying social and legal structures impose limits on action as guarantee certain rights. While Dewey takes no issue with imposing limits on action, he argues that simply guaranteeing certain rights (e.g., the freedom of speech) is not enough. 'There can be no greater mistake,' he wrote, then to 
treat such freedom as 'an end in itself' (LW 13, 41). Rather, he believed that societies should instead seek to effect a 'positive freedom' (LW 2, 340). This expression points to the enabling of society through the institution of conditions, which allow creative action to flourish (LW 11, 41). Inevitably, such a vision requires support structures, that is, an environment which allows individuals to grow and develop as they participate within community life. Unsurprisingly, then, Dewey discusses the concept in terms of education. On his view, when appropriately constituted, education should aim towards a 'freedom which is power'. Herein, students would be equipped to 'frame purposes, to judge wisely, to evaluate desires by the consequences which will result from acting upon them', as well as 'select and order means to carry chosen ends into operation' (LW 13, 41). It is this sense of positive freedom, this sense of enabling, of opening up possibility and potential, which sits behind Dewey's concept of creative democracy.

\section{Creative Democracy}

As was alluded to above, Dewey believed that political democracy and 'democracy as a way life' pointed to two distinct aspects of democratic organisation and activity. The former aspect is seen to concern the commonly recognised manifestations and characteristics of democratic governance, for example, universal suffrage, parliamentary representation, free speech and so on. The latter aspect extends much further and deeper, focusing in on the fine-grained complexities of the community-level interactions. Dewey believed that it is through the enactment of these interactions - as individuals become involved in group activities and cross-group exchanges occur - that the quality of democratic life is framed and defined.

Democracy then is not 'an alternative to other principles of associated life' but rather 'the idea of community life itself' (ibid, 328). It is here, along this baseline, that he locates the foundations of political democracy as expressed in his formulation of the 
publics concept outlined above. Fundamentally, and in contrast to the Marres-Latour STS account, his concept of the public is seen to act as a means of charting a connection between community-level interactions and the institutions of government - not merely an indication that an issue has escaped the 'normal routines of action'. The question of how to maintain such connections was, for Dewey, 'the problem of the public' (ibid, 365). Indeed, it was an issue he explored at length throughout his career. His frequent response was to sketch out the ideal of 'creative democracy' as the ultimate aim of democratic life (e.g., LW 11, 348-350; LW 14, 224-230). In this ideal scenario, multiple publics would have an equal opportunity to contribute to the deliberation and formation of social policy. At the same time, democratic government would enable new publics to interact with old publics (i.e., established political groups), and through this reform, reshape and remake its institutions in response to the currents of social change (see Narayan 2016, 37-38). Such a vision, Dewey proposed, could only be achieved through social intelligence.

\section{Social Intelligence}

The experimental method, with its emphasis on process, change and continuity, was central to Dewey's philosophy (e.g., LW 1, 339). He saw it as supporting a particular attitude, which aimed towards active problem-seeking; remarking that, through the experimentation, 'very new question [becomes] an opportunity for further experimental inquires - for effecting more directed change' (ibid, 81). For Dewey, social intelligence referred to the communal, society-wide adoption of the experimental method, linking communication to cooperative action and the exercise of collective judgement.

It was Dewey's proposal that the practice of social intelligence be adopted in the consideration of, and response to, emergent political and moral concerns. Publics and experts would work together to develop experimental policies and proposals (LW 2, 
362-365). These polices and proposals would be 'treated as working-hypotheses', subject to 'well-equipped' observation and potential revision (ibid, 362).

In terms of impact, Dewey believed that the practice of social intelligence within daily life would support a constant, on going cycle of 'discussion, debate and persuasion' amongst disparate groups (ibid, 365). This, in turn, would allow for the exploration and possible resolution of moral conflicts and disagreements (LW 11, 56). Additionally, from an institutional perspective, it was also held that an embedded social intelligence, i.e., an official commitment to cooperative inquiry, would bring about the ideal of creative democracy; that is, the possibility of government reform through an experimental response to the emergence of new needs (LW 2, 256, LW 11, 182).

\section{Some Implications of the Deweyan Democratic Vision for PD}

Dewey's democratic vision was framed in the early twentieth century, at a time of extreme political turmoil - fascism and communism were on the rise, the future of liberal democracy was under threat. Though our contemporary situation differs in many ways from Dewey's, it is arguable that the concerns he was addressing, whether relating to political ignorance, apathy or corruption, have echoes in our own time.

Returning to this article's original context - looking from PD's current appropriation of the publics concept to the possibilities of Dewey's wider vision - we many now ask what can the discipline learn from any further exploration of Dewey's democratic writings. At this point, it is important to recall the fact that Dewey was not presenting a prescription for action, but rather philosophical argument to aid reflection and promote change. Indeed, As Robert Westbrook cautions, it would be 'a mistake (and most un-Deweyan) to recommend an uncritical and wholesale recovery of Dewey's philosophy' but he does merit 'another, closer look' $(1991,552)$. This is the spirit in which I approach the work here. 
In particular, in this section, I would like to suggest that two horizons emerge through the interrelating of the publics concept, contemporary PD practice, and the trajectories of Dewey's wider democratic vision. The first is a why of democracy presented in the concept of positive freedom. The second is the initial outline for a how of democracy, found in the dual concepts of creative democracy and social intelligence. The former why may be seen to link to and enrich the existing conceptual context of PD as practiced. The latter how, on the other hand, opens up a set of possibilities for practice. I will now explore at both in turn.

As we have seen, positive freedom refers to the institution of conditions, which strengthen an individual or group's ability to frame and evaluate the means, ends and consequences of action, supporting their growth and development in longer term. Ultimately, this concept may be seen to function as a grounding orientation within Dewey's vision, a necessary undergirding for creative democracy and social intelligence, as well as an end in itself.

In drawing a link to the existing conceptual context of PD, I would like to propose that this has implications for the notion of infrastructuring. As presented by Ehn and colleagues, infrastructuring is said to denote the democratically motivated consideration 'of conditions that enable proper and legitimate user participation' (Bjögvinsson et al. 2012, 103) across contexts over time (Telier 2011, 171). I take the view that while this usefully points to the extended enabling of participation within PD, it does not properly capture the potentially transformative effects of these forms of participation for the participating individual, group or public.

This is regrettable as there is clear evidence for the presence of such a value in contemporary accounts of PD, including the cases highlighted above. For example, in discussing their engagement with the community group post-industrial decline, Le 
Dantec and DiSalvo note: 'the design team worked with the group to develop means by which the group could communicate their desires and challenges to others'. This included 'working to improve participants' skills in developing compelling descriptions of their project through both narratives and physical artefacts' (Le Dantec and DiSalvo 2013, 256, italics added). Here we observe the strengthening of particular skills. Through these interventions, participants are being supported in their efforts to frame the means, ends, and consequences of proposed action. As Le Dantec and DiSalvo make clear, these capacities were developed in the hope they would be transferable to future situations (257).

Thus, by aligning such instances with Dewey's concept of positive freedom, we may give form to an existing dimension in the design Things/infrastructuring/publics complex and, further, extend our understanding of the possible scope of practice. Additionally, it may be that, where appropriate, the concept can function as a motivational principle in the infrastructuring of design Things - a guiding Deweyan why.

Turning then to the dual concepts of creative democracy and social intelligence, we encounter what I consider to be the how of the Deweyan democratic vision. Here, with reference to creative democracy, I call attention to Dewey's belief that publics should, as a matter of course, be invited to contribute to the formation of social policy, as well as the process of institutional reform. Next to this, social intelligence - the broad-based adoption of experimental action - provides the outline of a method. Taken together, both concepts point to the desirability of opening up a creative, experimental linking of publics and institutions, policy formation and reform. As noted, this is extends further than the Marres-Latour presentation. By joining up the publics, creative 
democracy and social intelligence, Dewey is suggesting that in some cases, issues might have somewhere in particular to go, that a contingent protocol might be devised.

Returning to the context of PD, then, what does this distinct Deweyan contextualisation mean for practice? I believe that a possible forward path may be traced through the areas of design for policy and institutioning.

\section{Design for Policy}

Design for policy offers us an initial outline of how, through collaborative design practices, citizens might play a role in social policy formation. The practice has emerged through a series of government-sponsored programmes undertaken in countries such as Denmark, the UK, and France (Kimbell 2016, 1). Operating across various levels of government, these programmes have trialled collaborative, design-led approaches to policy formation. which, at least in part, draw on the legacy of PD (e.g., through the technique of prototyping, Kimbell and Bailey 2017, 215). Though research into this area is limited, a small but growing body of literature has begun accumulate around the subject. Across this work, one may detect a definite sense of 'promise' (e.g., Bason 2014; Kimbell and Bailey 2017) but, equally, the occasional expression of disquiet regarding design's role within this space (e.g., von Busch, Otto, and Palmås 2016).

The UK's Policy Lab based at the Cabinet Office in Westminster is perhaps the most widely studied design for policy programme (e.g., Kimbell 2016; Kimbell and Bailey 2017; Bailey 2017). Established in 2014, it aims to offer a 'neutral space' in which civil servants can engage with the public and specialists to explore 'key policy areas'. To date, project subjects have included 'policing in a digital age', family mediation and 'the future of aging' (Government Digital Service 2016). 
In a study of Policy Lab's work, Kimbell (2016) concludes that the lab has successfully demonstrated the viability of applying design approaches to central government's 'live policy issues'. Alongside this, she also observes that design holds the capacity to question 'the regular way of doing things' in policymaking (12).

In other writing, however, a less a positive view emerges. Kimbell and Bailey (2017) suggest that the notion of participation remains a significant challenge in such contexts; while traditional policymaking 'limits engagement with publics to avoid unwanted attention, contestation or politicisation', design may open it up (222). Bailey (2017) goes further. Reflecting on her experience as a practitioner in Policy Lab, she argues that 'at present the negotiation of issues and inclusion of publics... is highly selective, and dictated not by those publics, but by the politicians and policymakers in charge' (6-7).

\section{Institutioning}

Institutioning begins to point to a means by which institutional reform, in the Deweyan sense, may be achieved in the context of PD. The term has been proposed by Liesbeth Huybrechts and colleagues as a means of referring the multiple ways in which the activities of PD researchers and practitioners shape, and are shaped by, institutions (Huybrechts et al. 2017). Challenging PD's micro-level focus (as exemplified by the work of Ehn, DiSalvo and Le Dantec), the group argue that discipline must acknowledge its dependence on meso and macro level institutions (e.g., local, regional and national government). On their view, such an acknowledgement 'enables recognition' of PD's potential to effect direct and indirect changes in institutional policies and practices (155). 
The notion of institutioning arose in connection to the TRADERS project, a five-year, pan-European, multi-institution research project, exploring art and design research training through participation in the public realm. The project was undertaken through a series of smaller-scale initiatives, which each focused on a specific theme such as 'Intervention', 'Play', or 'Modelling in Dialogue'. Across these initiatives, researchers worked in partnership with a variety of local, third-party organisations (e.g., community centres, galleries and schools) to deliver bespoke workshops, events and exhibitions exploring their particular thematic (see Hamers et al. 2017).

Reflecting on the broader project, Huybrechts and colleagues (2017) highlight a number of instances where PD may be seen to have directed institutional change. For example, in two separate Gothenburg-based initiatives, city officials were introduced to new modes of youth engagement and art centres to new research and educational approaches. Further, as a result of the broader TRADERS project, many partner organisations were seen to incorporate participation within their institutional frameworks (154-156). For Huybrechts and colleagues, TRADERS demonstrates that the intentional enfolding of institutional change as 'an active and explicit component' of the PD process, suggests a means by which the discipline might work to reclaim its 'transformative heritage' (156-157).

\section{Connecting Publics to Government: PD and Creative Democracy}

Returning again to Dewey's vision, we can see how, in immediate terms, these examples link to his how of democracy, i.e., creative democracy via social intelligence, conceived of as experimentalism. Design for policy demonstrates the possiblity of enfolding design and citizen-involvement in the spaces of policy formation, albeit in a limited and problematic form (Bailey 2017). Institutioning suggests that recognising and 
valuing the potentiality of PD's institutional relations, as well as layering in an agenda of change, can produce results (Huybrechts et al. 2017). Though, of course, the TRADERS cases, in their own right, cannot be described as especially far-reaching.

Based on these examples, the question now becomes how might PD progress this work? If PD practitioners and researchers were to directly explore means by which publics might be connected government, as per Dewey's vision, how might they proceed?

Honing in on Bailey's critique of Policy Lab (2017, 6-7), I believe the opportunity lies in the experimental exploration of issue-framing and public-inclusion in formal democratic processes. Here, PD would aim to construct of spaces for interfacing; that is, devise design Things, which bring constituted publics into contact with institutions of government as part of an agonistic exchange; policy recommendations could sourced and appropriated, and desired future trajectories traced. Such work might involve prototyping, as in design for policy. It might involve or evolve an institutioning agenda - identifying, articulating and realising change in institutions - alongside enfolding or aiming towards positive freedom, a transformative enabling.

While this proposal may, at first, seem abstract, there are some relatable practical examples, which can be drawn upon. In case, Anders Emilson and Per-Anders Hillgren (2014) attempted to bring together civil servants and grassroots organisations in Malmö to explore the possiblity of establishing a city innovation hub. Though, ultimately, unsuccessful, they highlight how, through the inclusion of individuals in the role of 'intermediaries', they were able to 'spot ideas and translate dreams into a language that could be accepted by bureaucracy' (71). In another case, drawing on the theories of Dewey, Latour and others, Sissel Olander (2014) devised participatory approaches to enabling encounters between citizens and local politicians in community 
spaces. In this, at the same time as exploring the possiblity of establishing new institution platforms, new collaborations between formal and informal networks and new cultural collectives, she also queries local political procedures.

Again, these examples cannot be described as especially far reaching but they do offer a glimpse into some of the possible forms a publics-government interfacing might take. On the surface of it, it may be difficult to draw distinction between this proposal and the aims of present practice. However, the crucial point is that, in line with Dewey's vision, the possibility of connecting publics and government in policy formation and institutional reform is, at least, being considered.

Over the last decade, PD’s appropriation of the work of Marres, Latour and other STS scholars has simultaneously reformed and transformed the field. STS renews the tradition's ontological/epistemological positions, offering a productive poststructuralist perspective that opens up the intellectual interrogation of practice. What is proposed here should not be interpreted as standing in opposition to such developments. Rather, the particular Deweyan return I have argued for may be seen to act as a suggestion that latent opportunities are being overlooked; that, in some cases, it may be desirable to explore approaches to connecting publics to government. This is a Deweyan thread that Marres-Latour overlook, a creative how of democracy. Coupled with the why of positive freedom, it offers PD a further political horizon, a conceptual path to the consciousness meso and macro scaling of issues.

Of course, it is arguable that broad optimism of Dewey's vision in-the-round is wholly incompatible with the underlying philosophic commitments of Marres-Latour political perspective. How can Dewey's belief in the possiblity of creative democracy via social intelligence stand up against the powerhouse of post-structuralist thought, 
which, ultimately, would take a far less optimistic view of institutions and their willingness to accept change.

It is beyond the scope of the present article to examine the divide - bridgeable or unbridgeable - between Dewey's philosophy and post-structuralism. However, in relation to this issue, it is possible to argue that, despite claims to the contrary, Dewey was alert to power. Randy Hildreth (2009), for example, calls attention to what he sees as the implicit understandings of power and conflict in Dewey's writing. Equally, in demonstrating Dewey's awareness of malign political power, James Campbell foregrounds his deep criticisms of American democracy and concerns regarding propaganda and manipulation (see Campbell 1995, 249-257).

Beyond this, we must also note that, when assessing the value or viability of Dewey's democratic vision, it is important to appreciate the spirit in which it was originally presented. Dewey did not necessarily think that it was achievable or even possible. He was not an irrational optimist but, rather, a grounded meliorist (see MW 10, 181-182). He believed in the transformative potential of human action and intelligence, not in its guaranteed success. As such, his vision is offered as a hypothetical proposition worth pursuing, something to be tested in practice that may yet yield value.

On a final note, it must also be acknowledged that in offering this proposal, several questions remain outstanding. For example, what issues or publics deserve recognition? How to access power? How would the recommended publics-government interfacing carry any claims to legitimacy? Interpreted broadly, it would seem that these are questions that PD must grapple with regardless of context. As ever, the answers can only be found in practice - in this case, in the experimental mapping out of the space of creative democracy in response to the issues and publics encountered. 


\section{Conclusion}

In considering the potential of PD's relationship to formal democracy, the present article has returned to the democratic writings of John Dewey, via his publics concept and STS literature. I have argued that in following the STS definition of the publics concept, PD scholarship has lost sight of wider potential of Dewey's democratic vision. By exploring this vision, I identified a series of conceptual and practical implications for the field. Taken as a whole, these call attention to possiblity of consciously attending to the transformative aspect of participation in infrastructuring and the potential of developing spaces for interfacing; that is, the construction of design Things which aim to bring constituted publics into contact with government. Here, we encounter the publics of Dewey's vision and, in turn, the challenge of the vision for PD. 


\section{References}

Bailey, Jocelyn. 2017. "Beyond usefulness: Exploring the implications of design in policymaking." Paper presented at Nordes 2017, Oslo, June 15-17.

Bason, Christian. 2016. Design for Policy. Abingdon: Routledge.

Bjerknes, Gro, Pelle Ehn and Morten Kyng, Eds. 1987. Computers and Democracy - A Scandinavian Challenge. Aldershot: Avebury.

Björgvinsson, Erling, Pelle Ehn and Per-Anders Hillgren. 2010. "PD and democratizing innovation." In Proceedings of the 11th Biennial PD Conference, 41-50. New York: ACM.

Bjögvinsson, Erling, Pelle Ehn and Per-Anders Hillgren. 2012. "Design Things and Design Thinking: Contemporary PD Challenges.” Design Issues 28 (3): 101116.

Binder, Thomas, Eva Brandt, Pelle Ehn and Joachim Halse. 2015. "Democratic Design Experiments: Between Parliament and Laboratory." CoDesign 11 (3-4): 152165.

Campbell, James. 1995. Understanding John Dewey: Nature and Cooperative Intelligence. Chicago: Open Court Publishing.

Dewey, John. 1976-1988. The Middle Works of John Dewey, 1899-1924. 14 vols, edited by Jo Ann Boydston. Carbondale: Southern Illinois University.

Dewey, John. 1981-1991. The Later Works of John Dewey, 1925-1953. 14 vols, edited by Jo Ann Boydston. Carbondale: Southern Illinois University.

DiSalvo, Carl. 2009. "Design and the Construction of Publics." Design Issues 25 (1): 48-63.

Ehn, Pelle. 2017. "Learning in PD as I Found It (1970-2015)." In PD for Learning: Perspectives from Practice and Research, edited by Betsy DiSalvo, Jason Yip, Elizabeth Bonsignore and Carl DiSalvo 7-21. Abingdon: Routledge.

Emilson, Anders, and Per-Anders Hillgren. 2014. "Connecting with the Powerful Strangers: From Governance to Agonistic Design Things." In Making Futures: Marginal Notes on Innovation, Design and Democracy, edited by Pelle Ehn, Elisabet M. Nilsson and Richard Topgaard. Cambridge MA: MIT Press.

Government Digital Service. 2016. Open Policy Making Manual. Published January 4, 2016. https://www.gov.uk/guidance/open-policy-making-manual/getting-startedwith-open-policy-making 
Hamers, David, Naomi Bueno de Mesquita, Annelies Vaneycken and Jessica Schoffelen, eds. 2017. Trading Places: Practices of Public Participation in Art and Design Research. Barcelona: dpr-barcelona.

Hildreth, Roudy W. 2009. "Reconstructing Dewey on Power." Political Theory 37(6): 780-807.

Huybrechts, Liesbeth, Henric Benesch and Jon Geib. 2017. "Institutioning: Participatory Design, Co-Design and the Public Realm." CoDesign 13(3): 148159.

Kimbell, Lucy. 2016. "Design in the Time of Policy Problems." Paper presented at DRS2016: Design Research Society Conference, Brighton, June 27-30.

Kimbell, Lucy, and Jocelyn Bailey. 2017. "Prototyping and the New Spirit of PolicyMaking." CoDesign 13 (3): 214-226.

Latour, Bruno. 2005a. Reassembling the Social. Oxford: Oxford University Press.

Latour, Bruno. 2005b. "From Realpolitik to Dingpolitik or How to Make Things Public.” In Making Things Public: Atmospheres of Democracy, edited by Bruno Latour and Peter Weibel, 14-41. Cambridge, MA: MIT Press, ZKM/Center for Art and Media in Karlsruhe.

Latour, Bruno. 2007. "Turning around politics: A note on Gerard de Vries' paper." Social Studies of Science 37(5): 811-820.

Le Dantec, Christopher A. 2012. "Participation and publics: supporting community engagement”. In Proceedings of the SIGCHI Conference on Human Factors in Computing Systems, 1351-1360. New York: ACM.

Le Dantec, Christopher A. 2016. Designing Publics. Cambridge MA: MIT Press,

Le Dantec, Christopher. A., and Carl DiSalvo. 2013. "Infrastructuring and the formation of publics in PD." Social Studies of Science 43 (2): 241-264.

Marres, Noortje. 2007. "The Issues Deserve more Credit: Pragmatist Contributions to the Study of Public Involvement in Controversy." Social Studies of Science 37 (5): 759-780.

Marres, Noortje. 2012. Material Participation: Technology, the Environment and Everyday Publics. Basingstoke: Palgrave Macmillan.

Narayan, John. 2016. John Dewey: The Global Public and its Problems. Oxford: Oxford University Press. 
Olander, Sissel. 2014. The Network Lab: A Proposal for Design-Anthropological Experimental Set-Ups in Cultural Work and Social Research. Doctoral dissertation. Copenhagen: KADK.

Pappas, Gregory. 2008. Dewey's Ethics: Experience as Democracy. Bloomington, IN: Indiana University Press.

Sismondo, Sergio. 2003. An Introduction to Science and Technology Studies. Oxford: Blackwell.

Teli, Maurizio, Angela Di Fiore and Vincenzo D'Andrea. 2017. "Computing and the common: a case of Participatory Design with think tanks." CoDesign 13(2): 8395.

Telier, A., (Thomas Binder, Giorgio De Michelis, Pelle Ehn, Giulio Jacucci, Per Linde and Ina Wagner). 2011. Design Things. Cambridge MA: MIT Press.

Westbrook, Robert. 1991. John Dewey and American Democracy. Ithaca, NY: Cornell University Press.

von Busch, Otto, and Karl Palmås. 2016. "Designing Consent: Can Design Thinking Manufacture Democratic Capitalism?" Organizational Aesthetics 5(2): 10-24. 